\title{
Science in the Islamic Polity in the Twenty-First Century
}

\section{5-29 Shawwāl 1415 / 26-30 March 1995 \\ Islamabad, Pakistan}

This conference was a rare occasion for Muslim scientists and scholars to assemble and discuss the challenges facing the ummah. Inaugurated by Farooq Ahmad Khan Leghari, the president of Pakistan, the conference consisted of fifty papers presented in eight inaugural and plenary sessions. The issues discussed were of both theoretical and practical import.

The theoretical papers focused on such questions as the nature and significance of science, the concept of Islamic science, and Islamic epistemology. According to Ziauddin Sardar, who gave the public lecture "Islamic Science: The Way Ahead," science is a highly complex and multilayered activity, for

no single and simple description of science can reveal its true nature; no romantic ideal can describe its real character; no sweeping generalization can uncover its authentic dimensions. In particular, both the extreme positions of scientific fundamentalism and fundamentalist relativism are untenable.

He stated that science has been under the influence of the dominant westem paradigm and that the selection of research priorities is of fundamental importance in scientific research, for "often it is the source of funding that defines what problem is to be investigated." Some 80 percent of American research is funded by the "military-industrial complex" and is geared to producing military and industrial equipment.

As modem science is based on westem values and the priority given to scientific investigation is determined by western requirements, science must be indigenized. Muslim countries have a valuable and untapped reservoir of knowledge and experience, so such an indigenization would be like a rediscovery. But this process, Sardar maintains, "must begin by a rejection of both the axioms about nature, universe, time, and humanity as well as the goals and direction of western science and the methodology which has made meaningless reductionism, objectification of nature, and torture of animals its basic approach." By Islamic science he means a scientific activity pursued within the framework of a set of fundamental Islamic concepts. Sardar supports the concepts, identified by Muslim scientists at the Stockholm Seminar (1981), that should shape the science policies of Muslim societies: tawhid (unity), khiläfah (trusteeship), 'ihādah (worship), 
'ilm (knowledge), halāl (praiseworthy) and harām (blameworthy), 'adl (social justice) and zulm (tyranny), istișlāh (public interest), and dhiyät (waste). This is not a final list, for other concepts may be added. Sardar concluded that

only by developing science policies within the framework of the fundamental concepts of Islam, bringing these values to the level of laboratory and reorganizing the complexity of the issues and the difficulties involved in the solving of the problems generated by western science can we develop a contemporary relationship between Islam and science.

Expressing his views on the future of Islamic science, Sardar emphasized the importance of "strong objectivity ... a abjectivity that honestly declares its values and subjective elements up front." A science policy in the Islamic world, he says, "must be committed totally to the endeavor of knowledge generation." Citizen participation in formulating science policy, identifying areas of research at the ummatic level, and reviving traditional Islamic scientific knowledge should be the main considerations in planning future science policies, he remarked.

Seyyed Hussain Nasr, the eminent Iranian scholar, used his keynote address to discuss the nature of western science and the difference between western and Islamic approaches to science. From a modern scientific perspective, the hypothesis of God's existence is redundant to the existing system. It is commonly believed that western ethics is based on the Abrahamic faiths; thus, it is ironic that western scientific investigation rejects their knowledge of nature. Western science is "a direct challenge to other worldviews, including the Islamic, which claim a knowledge of reality which is not based on reason alone but also on revelation and inspiration." Since modern science has a particular value system, one must understand its philosophical foundations and how it relates to the Islamic worldview. He observed that, as many in the West are interested in alternate views of reality, it seems appropriate to present the Islamic scientific approach. Islamic science, he said, "must be drawn from haquiqah, which lies at the heart of the Noble Qur'an and hadith and as expounded and formulated by the traditional commentators, as well as from Islamic metaphysics, cosmology, and the doctrinal and intellectual aspects of Sufism." To achieve this, Nasr suggested that

there must be an in-depth study of the traditional source from the Noble Qur'an and hadith to all the traditional works on the sciences, philosophy, theology, cosmology, and the like to formulate the Islamic worldview and especially the Islamic concept of nature and sciences of nature. This arduous and yet necessary task must be carried out within the framework of the Islamic intellectual tradition itself and not simply by going to certain verses of the sacred 
book, often taken out of context, and interpreting them by ourselves, by a mind usually cluttered by ideas, issues, and ideologies as far removed from Islam as possible.

He stressed further that traditional Islamic sciences, especially in the fields of medicine, pharmacology, agriculture, and architecture, must be revived.

Recalling the ummah's scientific legacy, Syed Noman ul Haq (Brown University) pointed out in "Western Approaches to the Scientific Legacy of Islam" that "there are literally hundreds of thousands of Arabic scientific manuscripts lying unread in various libraries all over the world." $\mathrm{He}$ deserves our consideration when he says: "In fact, until our work on reconstructing the corpus of Arabic scientific writings is complete, we can hardly characterize [this corpus as] Islamic science, nor can we definitively periodize it, nor can we thoroughly evaluate its worth." Therefore, before commenting on the scientific work of earlier Muslims scholars: "Let us real al Ghazali before we express an opinion on him."

Mehdi Gulshani (Iran) highlighted various theories about God's existence that have emerged in contemporary physics. In his "Islam and Socio-Scientific Postmodernism," Masudul Alam Choudhury criticized strongly the occidental epistemology characterized by individualism, plurality, and dualism and proposed a "unification epistemology" framework emanating from the Qur'an and nature. He examined critically the idea of postmodernity with regard to structuralism, poststructuralism, and historicism.

Sohail Inayatullah, N. A. Baloch, Nasim Butt, and other participants underlined important aspects of the Muslim understanding of the universe and the location of science in Islamic discourse. Naumana Amjad (Punjab University, Lahore) stressed the importance of traditional religious wisdom in understanding human behavior. She opined further that Islamic psychology should be described in contemporary empirical terms, which she sought to do by identifying points of convergence and conflict between traditional Islamic psychology and modern empirical psychology.

Many papers discussed the ummah's prevailing socio-politico-cultural condition and suggested some remedies. Khalid Masud, Ahmad Yuksel Ozmere, and Qaisar Mushtaq highlighted reasons for the decline of Muslim scientific activity and creativity, while Ghulam M. Hanif analyzed current educational conditions and the general level of awareness. His depressing scenario and supporting statistics initiated a debate, as several individuals opined that statistics coming from western sources are often distorted deliberately to create pessimism in the Muslim world and to increase western dependency. Anuar A. Razzaq (Malaysia) supported and reinforced this thesis with various statistics, among them the following: the top ten purchasers of American weapons are Saudi Arabia (US $\$ 30.4$ ), Egypt (US $\$ 4.4$ billion), Kuwait (US $\$ 3.8$ billion), and Turkey (US $\$ 3.3$ billion). 
There was some optimism: Sudanese and Malaysian successes in science and technology were related by Shabbir Hussain, Taj Eldin Faysal Abushama, and Anuar A. Razzaq. Sudanese universities and research centers have multiplied during the last five years, student enrollment has risen sixfold, and about twenty new universities have been opened. The continuing modernization of health services, agricultural practices, transport, communication, and industry is due mainly to local expertise and locally produced equipment. Malaysian achievements are a model for the ummah.

A. Q. Khan, a prominent Pakistani scientist, highlighted Muslim difficulties in scientific and technological fields due to western monopolistic designs. He said that Muslim students are discriminated against in western institutions of natural science and engineering, denied access to sensitive scientific and technological fields, and suffer from a private-sector ban that seeks to restrict the flow of sophisticated technical services to the ummah. He ended with a plea that science and technology be indigenized.

There was, nevertheless, a consensus that technology, regardless of the approach adopted, is a prerequisite for true independence.

A significant part of the debate was devoted to academic challenges derived from current medical science developments affecting the Muslim social structure, most notably family planning and artificial insemination. Muhammad Mian Siddiqi and M. M. Qureshi discussed family planning and concluded that "persons having a high level of nutrition and educational training should be encouraged to produce relatively larger numbers of children, while those lacking these facilities should be discouraged." They cited Qur'an 4:3 (allowing polygamy) and 4:25 (continence for the unmarried), verses that seem totally irrelevant to their thesis and out of context. On the whole, they seemed to support family planning.

Artificial insemination was discussed by Saeed Akhtar and M. A. K. Lodhi, who explained its historical background, process, and implications. They highlighted the difference between artificial insemination homologous (AIH) and artificial insemination donor (AID) and opined that the former, which uses the husband's semen and has a success rate of zero to 58 percent, seems legitimate. The success rate of the second method, which uses the semen of a donor who is not the woman's husband, varies from 52 percent to 98 percent, is controversial, and was not supported by the authors. They suggested that certain alterations would make it acceptable.

A unanimous declaration, adopted during the concluding session and after some discussion, recommended that:

1. An International Institute for the Study of Science be established to: a) study the history and philosophy of science and technology; b) conduct future science and technology studies in subjects relevant to the ummah; c) advise Muslim educational institutions on matters related to scientific curriculum developments; d) provide accurate and balanced information on Islam to the international media; and e) gather and disseminate information about Muslim scholars, scientists, and thinkers. 
2. An International Forum of Muslim Scientists and Scholars be set up to: a) help revive the spirit of a unified ummah via collective and creative thinking; b) serve as a forum to exchange information, ideas, and visions; c) monitor the international media's representation of events in the ummah and propose necessary remedial steps to Muslim governments; d) formulate a clear expression of the nature and characteristics of the Islamic framework of scientific investigation; e) clarify ideas, theories, and systems arising out of the ummah's inner dynamics; and f) articulate the aims and purposes of scientific applications to develop appropriate technology.

The declaration appealed to scientific communities in the Muslim world, policy and decision makers, private sector entrepreneurs, and the heads of Muslim nations to: a) strive for true political, economic, and intellectual independence so they can be equal players on the world stage; b) create an environment that promotes self-criticism and an uncompromising self-confidence; and c) revive the spirit of Muslim brotherhood.

Hakim Muhammad Said, Mehdi Golshani, S. M. Qureshi (secretary, Ministry of Science and Technology, Pakistan), Ziauddin Sardar, Faysal Tag Eldin Abushama, Zafar Ishaq Ansari (director general, Islamic Research Institute, Pakistan), Munawar Anees (editor-in-chief, Periodica Islamica), and M. A. Kazi (coordinator general, COMSTECH) chaired the plenary sessions.

This conference provided a forum for a frank discussion of problems and possible solutions. It was observed that Muslim scholars who no longer live in the Muslim world think differently than their counterparts who do: The former are more theoretically inclined, maybe even a little romantic, in their approach, while the latter are more practical and pragmatic.

The dedication of Muslim scholars and scientists to Islam and their urge to indigenize different academic disciplines is admirable. Since present natural and social science syllabi cannot construct an Islamic view, facilities should be provided for seniors to adequately equip themselves in Islamic studies. An additional knowledge of the Qur'an, the Sunnah, and Arabic, along with competence in their particular subject, will make their approach more authentic and significant. The behavior of Muslim governments and their low interest in science and technology was also discussed. It was recommended that the private sector should be urged to participate in different scientific development plans. Any joint effort of Muslim businessmen and scientists in the field of science and technology will certainly be a step in the right direction.

Khurshid Ahmad Nadeem

International Institute of Islamic Thought

Islamabad, Pakistan 